\title{
Nutritional and Technological Quality of High Protein Pasta
}

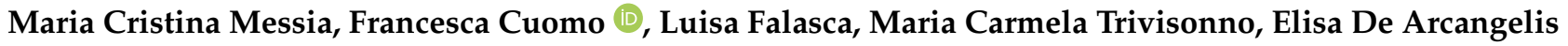 \\ and Emanuele Marconi *
}

check for updates

Citation: Messia, M.C.; Cuomo, F.;

Falasca, L.; Trivisonno, M.C.; De

Arcangelis, E.; Marconi, E. Nutritional and Technological Quality of High Protein Pasta. Foods 2021, 10, 589. https://doi.org/10.3390/foods10030589

Academic Editors: Francesca Nocente and Laura Gazza

Received: 12 February 2021

Accepted: 8 March 2021

Published: 11 March 2021

Publisher's Note: MDPI stays neutral with regard to jurisdictional claims in published maps and institutional affiliations.

Copyright: (C) 2021 by the authors. Licensee MDPI, Basel, Switzerland. This article is an open access article distributed under the terms and conditions of the Creative Commons Attribution (CC BY) license (https:/ / creativecommons.org/licenses/by/ $4.0 /)$.
Department of Agricultural, Environmental and Food Sciences (DiAAA), University of Molise, Via F. De Sanctis snc, 86100 Campobasso, Italy; messia@unimol.it (M.C.M.); francesca.cuomo@unimol.it (F.C.); falasca@unimol.it (L.F.); mariacarmela.trivisonno@unimol.it (M.C.T.); elisa.dearcangelis@unimol.it (E.D.A.)

* Correspondence: marconi@unimol.it

Abstract: Pasta has an important role in human nutrition for its high content of complex carbohydrates and its widespread use. It can be an efficient delivery system or carrier of non-traditional raw material, including additional health-promoting ingredients. The partial replacement of semolina with high-protein raw materials leads to the improvement of the biological value of pasta proteins. In order to obtain pasta with high nutritional protein value and with excellent cooking properties, various recipes have been formulated with different percentages of semolina and unconventional high-protein raw materials (peas and soy isolate proteins, egg white, whey proteins and Spirulina platensis). High-protein pasta was produced using a pasta making pilot plant and the nutritional quality (protein content and quality) and sensorial properties were assessed. All experimental pastas showed optimal performances. Pasta prepared with pea protein isolate, whey proteins and Spirulina platensis showed improved chemical score and digestible indispensable amino acid scores, an eye-catching color, and an excellent cooking quality.

Keywords: pasta; unconventional ingredients; nutritional value; cooking quality; legumes; Spirulina Platensis

\section{Introduction}

Pasta is a foodstuff with an important role in human nutrition. It is popular with consumers for its easy handling, storage and preparation. In addition to its high content of complex carbohydrates with low glycaemic index, pasta also contains proteins. The quality of a protein is substantially related to its composition in essential amino acids and its digestibility. High-quality proteins contain all the essential amino acids at levels equal to or higher than those of the reference amino acid pattern of FAO/WHO/UN [1]. On the contrary, nutritionally incomplete or low biological value proteins are those lacking or deficient in one or more essential amino acids. All proteins of animal origin, with the exception of collagen, are considered complete proteins, while vegetable proteins, with a few exceptions, have a relative deficiency in certain essential amino acids. The limiting amino acid is the essential amino acid present in a protein in the lowest quantity, thus arginine is the limiting amino acid for casein, methionine for fish and egg proteins, and lysine is the amino acid of which commonly vegetable proteins are more deficient, especially those of cereals and cereal-based foods, such as pasta. In this context, the chemical score (CS) is the parameter used to describe the quality of proteins in terms of the potential ability of the dietary protein to provide the appropriate amount of essential amino acids. Proteins with a CS close or equal to 100 are considered better nutritionally, and therefore able to adequately meet human needs.

The interest in protein supplements is particularly exhibited by athletes and by people who need to bring a greater amount of protein into their diet. The protein requirement of the adult can increase significantly with sporting activity, starting from a base value, indicated in the LARN (Livelli di Assunzione di Riferimento di Nutrienti ed energia) [2], 
of $0.8 \mathrm{~g} / \mathrm{kg}$ (protein $/ \mathrm{kg}$ of body weight), useful for the sedentary subject, to values higher than $1.5 \mathrm{~g} / \mathrm{kg}$, indicated to cover the athlete's needs for the growth, maintenance, and repair of muscle [3-8]. However, it should be noted that adopting a diet very rich in proteins can lead to a reduction in carbohydrate intake, since sportspeople usually adhere to strict and scrupulous daily energy intakes. This imbalance in the diet could be counterproductive and potentially harmful in terms of health. There is a widespread belief among body builders that a high-protein diet, further integrated with purified proteins, is the fundamental factor for the development of muscle mass. The protein requirement increases if the training is aimed at developing strength and therefore muscle trophism, or if the training load is particularly intense. The use of nutritional supplements is very widespread among athletes of different levels, although the scientific literature does not report any data on their functions and their effects, which are instead promoted to the public. However, regardless of sportsmen, consumers are currently changing their eating habits thanks to the greater awareness they are acquiring regarding the well-being that a diet rich in foods of plant origin and low in foods of animal origin brings, both to the body and to the environment [9]. As shown by Ranganathan and coworkers [10], it is more expensive to obtain animal resources than plant-based ones. This aspect represents one of the main reasons for orienting new food styles towards other sustainable and effective sources able to provide high-quality food production while coping with population growth.

The commercial segment of high-protein pasta, driven by particular nutritional needs but also by food trends, has been growing in recent years. The nutritional needs required by consumers (higher protein content) have been met by the food industry, as demonstrated by the numerous products on the market. Innovative pasta recipes, including the replacement of semolina with alternative ingredients, have already been proposed, and non-traditional raw materials, soybean, pea, bean, chickpea flours or isolates, but also milk products such as whey proteins, casein and powdered milk, could be used [11-13]. In particular, legumes represent an interesting source of nutrients (protein, minerals, fiber) [14], and represent a valid ingredient in the development of diets that are healthy to humans and sustainable for the environment, since they can help to mitigate environmental climate change by reducing the carbon and water footprint [15]. Therefore, there has been an increasing interest in integrating legumes into food production. Although legumes' proteins are relatively low in sulfur amino acids and tryptophan, they have high lysine contents. Consequently, legumes and cereals are nutritionally complementary. The partial replacement of semolina with legume flours in the preparation of pasta leads to the improvement of the protein biological value and the amino acid CS.

More recently, microalgae and cyanobacteria such as Chlorella spp., Dunaliella spp., and Spirulina spp. are becoming more popular as new, highly nutritious food ingredients [16-18]. Spirulina platensis (spirulina) is rich in digestible protein, fat with unsaturated fatty acids, mineral, clorophyll and B group vitamins, in particular B12 vitamin $[19,20]$. For its characteristics, spirulina has been proposed for different food preparations, such as yogurt [21], snacks [22], or in Indian recipes [23] for the development of functional foods. Moreover, some studies have demonstrated the potential of this microalgae in the prevention and treatment of diseases related to metabolic syndrome [24]. Recently, a study has been published wherein spirulina has been used as a filling, together with other ingredients, in stuffed pasta [25]. The investigation was mainly focused on the acceptance of consumers of spirulina, and it emerged that its taste is accepted only in small amounts. Another recent study [26] used spirulina encapsulated in alginate microcapsules in the production of fresh pasta prepared with wheat flour. Encapsulation partially protects spirulina from the loss of its antioxidant potential, and the pasta presented green dots of a non-uniform color on the surface, which did not negatively influence the consumer's judgement.

Using legumes and spirulina as food ingredients represents an opportunity to reconcile the food system with the needs of the planet, and to encourage a healthy and balanced diet with beneficial effects for both humans and the environment, as indicated in the latest 
European strategies on the agri-food system "From Farm to Fork Strategy—For a fair, healthy and environmentally friendly food system and Green Deal" [27].

However, the amount of high-protein material that can be added to or substituted for semolina represents a compromise between nutritional improvement and the achievement of satisfactory sensory and functional properties in pasta. Often, improving protein quantity and quality in pasta by the addition of various raw materials from plant or animal sources can lead to a decrease in pasta's sensory and cooking qualities.

Based on the above considerations, here, soy protein isolate, pea protein isolate, whey proteins, and spirulina were proposed as additional ingredients to improve the nutritional quality of semolina pasta. The ingredients were used to produce high-protein pasta, and the effects on the nutritional and cooking quality properties were investigated and compared with $100 \%$ semolina pasta.

\section{Materials and Methods}

\subsection{Ingredients}

Soy protein isolate (ABS FOOD srl, Peraga di Vigonza (PD), Italy), peas protein isolate (ABS FOOD srl, Peraga di Vigonza (PD), Italy), egg white (EUROVO srl, Bologna, Italy), whey proteins (Volac International Ltd., Hertfordshire, UK), high-quality durum wheat semolina (high protein, gluten index $=95$ ) from a local distributor, and Spirulina platensis (spirulina) (ATI Biotech, Napoli, Italy) were used as ingredients to develop highprotein pasta.

\subsection{Commercial Pasta}

Five short commercial pastas ("rigatoni" and "penne" shape) with high protein contents were purchased in a local supermarket. The protein content and the ingredients listed on their label are shown in Table 1.

Table 1. Protein content and ingredients of commercial high-protein pasta (CP).

\begin{tabular}{|c|c|c|}
\hline Sample & Protein $(\%)$ & Ingredients \\
\hline $\mathrm{CP} 1$ & 60 & soy protein isolate, wheat flour, gluten, egg white, pea protein, wheat fiber, inulin, guar gum \\
\hline $\mathrm{CP} 2$ & 40 & semolina, pea protein, egg \\
\hline $\mathrm{CP} 3$ & 60 & $\begin{array}{l}\text { gluten, wheat flour, soy protein isolate, egg white powder, whey proteins, pea protein, wheat fiber, } \\
\text { guar gum }\end{array}$ \\
\hline $\mathrm{CP} 4$ & 52 & vegetal proteins (soy, pea), semolina, egg white, sodium alginate, L-methionine, L-threonine \\
\hline CP5 & 65.1 & soy protein, lentil flour, pea protein, calcium caseinate, egg \\
\hline
\end{tabular}

\subsection{Proximate Composition}

Moisture, ash and lipid content were determined according to the ICC methods 109/1, 104/1 and 136, respectively [28]. The dietary fiber was determined according to the AACC method 32.05 [29]. Protein content $(\mathrm{N} \times 6.25)$ was determined according to the Dumas combustion method (AACC method 46-30) [29], using a Leco nitrogen determiner, model FP 528 (Leco Corp., St. Joseph, MI, USA).

\subsection{Amino Acids Analysis and Chemical Score}

Amino acids were analyzed after acidic and alkaline hydrolysis. Acidic hydrolysis: a sample, corresponding to $25 \mathrm{mg}$ of protein, was hydrolyzed with $25 \mathrm{~mL}$ of $6 \mathrm{~N} \mathrm{HCl}$ at $110^{\circ} \mathrm{C}$ for $24 \mathrm{~h}$. Afterwards, the sample was cooled, filtered, evaporated to dryness and re-dissolved in $0.1 \mathrm{~N} \mathrm{HCl}$. Alkaline hydrolysis for tryptophan: a sample containing $10 \mathrm{mg}$ of protein was added to $1 \mathrm{~mL}$ of distilled water, shaken, supplemented with $10 \mathrm{~N} \mathrm{NaOH}(5 \mathrm{~mL})$ and distilled water $(4 \mathrm{~mL})$, and then hydrolyzed for $18 \mathrm{~h}$ at $110{ }^{\circ} \mathrm{C}$. After cooling, the sample was neutralized by adding $6 \mathrm{~N} \mathrm{HCl}$, evaporated to dryness, and re-dissolved in $0.1 \mathrm{~N} \mathrm{HCl}$. Before analysis, all samples were diluted 1:50-1:100 with ultra-pure water, and analyzed by an 
ICS6000 chromatographic system (Thermo Fisher Scientific S.p.A, Milano, Italy). Separation was performed with an Aminopac PA10 analytical column $(250 \times 2 \mathrm{~mm}, 8.5 \mu \mathrm{m}$ particle size $)$ (Thermo Fisher Scientific S.p.A, Milano, Italy). Chromatographic separation of the amino acids was performed according to the following conditions (Table 2).

Table 2. Conditions for chromatographic separation of amino acids.

\begin{tabular}{|c|c|c|c|c|c|c|}
\hline \multicolumn{4}{|c|}{ Mobile Phase $(0.250 \mathrm{~mL} / \mathrm{min})$} & \multicolumn{3}{|c|}{ Time/Potential Waveform } \\
\hline Time (min) & $\mathrm{H}_{2} \mathrm{O}(\%)$ & $\mathrm{NaOH}(\%)$ & NaOAc (\%) & Time (sec) & Potential (V) & Integration \\
\hline 0.0 & 80 & 20 & 0 & 0.00 & +0.13 & \\
\hline 2.0 & 80 & 20 & 0 & 0.04 & +0.13 & \\
\hline 12.0 & 80 & 20 & 0 & 0.05 & +0.28 & \\
\hline 16.0 & 68 & 32 & 0 & 0.11 & +0.28 & began \\
\hline 24.0 & 36 & 24 & 40 & 0.12 & +0.60 & \\
\hline 40.0 & 36 & 24 & 40 & 0.41 & +0.60 & \\
\hline 40.1 & 20 & 80 & 0 & 0.42 & +0.28 & \\
\hline 42.1 & 20 & 80 & 0 & 0.56 & +0.28 & end \\
\hline 42.2 & 80 & 20 & 0 & 0.57 & -1.67 & \\
\hline \multirow[t]{3}{*}{62.0} & 80 & 20 & 0 & 0.58 & -1.67 & \\
\hline & & & & 0.59 & +0.93 & \\
\hline & & & & 0.60 & +0.13 & \\
\hline
\end{tabular}

Chemical score (CS) and digestible indispensable amino acid score (DIAAS\%) were calculated according to the Food and Agriculture Organization [1] using the recommended amino acid scoring pattern for older children, adolescents and adults.

\subsection{Pasta Making}

Short pasta (rigatoncini shape) was manufactured through an experimental pasta making apparatus (NAMAD, Roma, Italy) composed of a press and a dryer following the approved method 66-41 [29]. The press (capacity 10-20 kg) was equipped with a vacuum-mixing and -extruding system, as well as with a water-cooling jacket for the barrel and the extrusion head to reduce heat and to maintain a constant extrusion temperature lower than $50{ }^{\circ} \mathrm{C}$. The static dryer was equipped with a heat ventilator unit, to ensure uniform temperature and ventilation in all parts of the apparatus, and a moisture control unit. Semolina and other ingredients were mixed for $15 \mathrm{~min}$ with tap water $\left(30^{\circ} \mathrm{C}\right)$ to obtain a dough suitable for extrusion. Extrusion occurred at $30 \pm 2{ }^{\circ} \mathrm{C}$ and at a pressure of $76 \pm 5$ bar. Each series of short pasta was dried at a maximum temperature of $50{ }^{\circ} \mathrm{C}$ for $24 \mathrm{~h}$. At the end of the drying cycle pasta was conditioned at room temperature $\left(\sim 20^{\circ} \mathrm{C}\right)$ for $24 \mathrm{~h}$.

\subsection{Pasta Characterization}

Optimum cooking time, firmness (by chewing), liveliness (by manual handling) and starch release (by manual handling) were determined according to International Standard ISO 7304-1 [30]. A rating scale ranging from 10 to 100 was used (Table 3). A panel of 10 trained judges was used to assess pasta characteristics. The total score was calculated by adding together the ratings obtained for firmness, liveliness and starch release and then dividing the sum by 3 .

\subsection{Statistical Analysis}

Data reported for all parameters are the average values of measurements obtained from the analysis of three different aliquots of each sample, and were expressed as mean \pm standard deviation (mean value $\pm \mathrm{sd}$ ). Analysis of variance (ANOVA) and Tukey HSD tests were performed on the protein content and cooking quality scores of the experimental pastas using RStudio version 1.2.5033 (RStudio Team (2019). RStudio: Integrated Development for R. RStudio, Inc., Boston, MA, USA, http:/ / www.rstudio.com/ (accessed on 3 March 2021)). Significant differences were set for $p<0.05$. 
Table 3. Rating scale for pasta sensory analysis [30].

\begin{tabular}{|c|c|c|}
\hline Firmness & Liveliness & Starch Release \\
\hline 100-very high (very firm) & 100-very high (not at all sticky) & 100-very low (no starch) \\
\hline 80-high & 80-high & $80-$ low \\
\hline 50-medium & 50-medium & 50-medium \\
\hline 30 -low & 30 -low & 30-high \\
\hline 10—very low (very tender) & 10-very low (very sticky) & 10 - very high (large quantity of starch) \\
\hline
\end{tabular}

\section{Results}

\subsection{Cooking Quality Assessment of Commercial High-Protein Pasta}

The nutritional needs of consumers are met by the food industry, as demonstrated by numerous products on the market. Five commercial pastas with a high protein contents (ranging between 40 and 65\%) were checked for composition and ingredients. As shown in the list of ingredients (Table 1), the abovementioned pastas included a wide range of ingredients such as soy protein, pea protein, lentils flour, eggs, egg white, inulin, caseinate and gluten, in addition to the presence of additives such as E412 (guar gum) and E401 (sodium alginate), and it emerged that they were prepared by reducing or annihilating the percentage of durum wheat semolina used in the formulation. Moreover, food additives, such as guar gum are commonly used as structuring agents with the aim of replacing the gluten that is missing in the alternative ingredients used to increase the protein content. Although commercial pastas satisfy the requirement related to the high protein content, they are not always able to satisfy the consumer from a sensorial point of view.

\subsection{Characterization of Raw Materials for High-Protein Pasta Production}

Durum wheat semolina, due to the rheological properties of its proteins (gluten) and the high content of pigments, is considered the best raw material for pasta making. The preparation of pasta with unconventional ingredients is challenging due to the absence/reduced formation of the protein network that prevents the disintegration of the pasta during cooking. In this experimentation, the possibility of using semolina in combination with other high protein raw materials to produce pasta with high protein content, improved protein quality and optimum cooking quality was studied. In order to only partially replace the semolina, among the possible ingredients, we tested protein isolates of soy and pea, egg white, whey proteins and spirulina.

To obtain excellent quality pasta, without the adjuvants/additives (e.g., guar gums, sodium alginate) generally enclosed in the recipes of commercial pasta, high-protein and high-gluten semolina was used. To counteract the lack of gluten and help the formation of a cohesive mass, we chose to add egg white and whey proteins, as widely reported in the literature [31,32].

The proximate composition of semolina and unconventional raw materials used for the production of experimental high-protein pasta is reported in Table 4.

For the selected raw material, the amino acids content, the CS, and the definition of the limiting amino acid, calculated on the basis of the Food and Agriculture Organization's described pattern [1], were assessed (Table 5). 
Table 4. Proximate composition (g/100 g d.w.) of wheat semolina and other raw materials.

\begin{tabular}{|c|c|c|c|c|c|}
\hline Sample & Protein & Lipid & Ash & Carbohydrates * & Fiber \\
\hline Wheat Semolina & $14.3 \pm 0.01$ & $1.5 \pm 0.02$ & $0.8 \pm 0.00$ & 79.2 & $4.2 \pm 0.30$ \\
\hline Soy Protein Isolate & $90.0 \pm 0.21$ & $1.1 \pm 0.01$ & $6.5 \pm 0.11$ & 1.3 & $1.1 \pm 0.23$ \\
\hline Pea Protein Isolate & $87.9 \pm 0.05$ & $2.0 \pm 0.02$ & $6.9 \pm 0.21$ & 1.4 & $1.8 \pm 0.43$ \\
\hline Egg White & $89.2 \pm 0.12$ & $0.0 \pm 0.00$ & $8.3 \pm 0.05$ & 0.0 & $0.0 \pm 0.00$ \\
\hline Whey Proteins & $91.8 \pm 0.81$ & $0.4 \pm 0.00$ & $2.1 \pm 0.23$ & 5.7 & $0.0 \pm 0.00$ \\
\hline Spirulina & $58.5 \pm 0.32$ & $8.9 \pm 0.15$ & $7.3 \pm 0.45$ & 20.8 & $4.5 \pm 0.30$ \\
\hline
\end{tabular}

* Calculated by difference.

Table 5. Amino acid (g/100 g protein), chemical score (CS) and limiting amino-acid of soy protein, peas protein, egg white, whey proteins and wheat semolina.

\begin{tabular}{|c|c|c|c|c|c|c|}
\hline $\begin{array}{l}\text { Essential Amino } \\
\text { Acids }\end{array}$ & Soy Protein Isolate & $\begin{array}{l}\text { Peas Protein } \\
\text { Isolate }\end{array}$ & Egg White & $\begin{array}{l}\text { Whey } \\
\text { Proteins }\end{array}$ & Wheat Semolina & $\begin{array}{l}\text { FAO [1] Amino } \\
\text { Acid Scoring } \\
\text { Patterns (mg/g) }\end{array}$ \\
\hline Histidine & $2.29 \pm 0.13$ & $3.50 \pm 0.09$ & $2.20 \pm 0.05$ & $2.13 \pm 0.03$ & $2.05 \pm 0.11$ & 16 \\
\hline Isoleucine & $3.92 \pm 0.22$ & $1.65 \pm 0.08$ & $5.35 \pm 0.09$ & $7.12 \pm 0.10$ & $3.69 \pm 0.07$ & 30 \\
\hline Leucine & $7.49 \pm 0.01$ & $7.80 \pm 0.08$ & $8.06 \pm 0.30$ & $11.35 \pm 0.55$ & $7.07 \pm 0.05$ & 61 \\
\hline Lysine & $5.69 \pm 0.14$ & $6.63 \pm 0.31$ & $6.78 \pm 0.21$ & $9.83 \pm 0.13$ & $2.09 \pm 0.24$ & 48 \\
\hline Methionine & $1.20 \pm 0.04$ & $0.25 \pm 0.22$ & $3.94 \pm 0.10$ & $2.25 \pm 0.09$ & $1.56 \pm 0.08$ & \multirow{2}{*}{$\begin{array}{l}\text { Methionine + } \\
\text { Cysteine } 23\end{array}$} \\
\hline Cysteine & $1.84 \pm 0.04$ & $1.48 \pm 0.09$ & $2.92 \pm 0.05$ & $2.51 \pm 0.21$ & $2.45 \pm 0.07$ & \\
\hline Phenylalanine & $4.86 \pm 0.15$ & $5.99 \pm 0.12$ & $5.85 \pm 0.15$ & $3.44 \pm 0.28$ & $4.89 \pm 0.19$ & \multirow{2}{*}{$\begin{array}{c}\text { Phenylalanine }+ \\
\text { Tyrosine } 41\end{array}$} \\
\hline Tyrosine & $3.41 \pm 0.22$ & $2.68 \pm 0.08$ & $4.19 \pm 0.19$ & $3.42 \pm 0.56$ & $2.56 \pm 0.09$ & \\
\hline Threonine & $3.77 \pm 0.00$ & $3.19 \pm 0.10$ & $4.67 \pm 0.09$ & $7.72 \pm 0.02$ & $2.77 \pm 0.04$ & 25 \\
\hline Valine & $3.98 \pm 0.07$ & $4.64 \pm 0.13$ & $6.84 \pm 0.10$ & $6.65 \pm 0.23$ & $4.33 \pm 0.01$ & 40 \\
\hline Tryptophan & $0.51 \pm 0.02$ & $1.15 \pm 0.09$ & $1.60 \pm 0.07$ & $1.93 \pm 0.04$ & $0.98 \pm 0.02$ & 6.6 \\
\hline Chemical Score (CS) & 77 & 79 & 100 & 100 & 44 & \\
\hline Limiting Amino acid & Tryptophan & $\begin{array}{l}\text { Sulphur amino acid } \\
\text { (Met + Cys) }\end{array}$ & - & - & Lysine & \\
\hline
\end{tabular}

\subsection{Definition of Pasta Recipes and Pasta Cooking Quality}

Different formulations for high-protein pasta were hypothesized in order to produce pasta with a protein content above $40 \%$ and an improved CS (90-100\%) compared to $100 \%$ semolina pasta. The formulations were studied, taking into account the costs of raw materials, and including ingredients at appropriate quantities to obtain a final product with acceptable sensorial characteristics and good cooking quality. Moreover, salt was not added to ensure that the salt in the pasta was due only to the sodium naturally contained in the ingredients, and also to meet the needs of consumers as regards preventing arterial hypertension. Spirulina (1\%) as a source of proteins and color was also included among the ingredients for pasta production (formulation FHP2, FHP4, FHP6 and FHP8).

The hypothesized formulations are shown in Table 6.

High-protein short pastas ("rigatoncini" shape) were produced, starting from the formulations in Table 6 . The $100 \%$ semolina pasta was used as the control sample. The results for the protein content, chemical score, DIAAS\%, optimal cooking time and cooking quality of all produced pastas are reported in Table 7. 
Table 6. Hypothesized high-protein pasta formulations (FHP).

\begin{tabular}{|c|c|c|c|c|c|c|}
\hline \multirow{2}{*}{ Formulation } & \multicolumn{6}{|c|}{ Ingredients (\%) } \\
\hline & Wheat Semolina & Soy Protein Isolate & Pea Protein Isolate & Egg White & Whey Proteins & Spirulina \\
\hline FHP0 & 100 & 0 & 0 & 0 & 0 & 0 \\
\hline FHP1 & 44 & 17.4 & 30.8 & 7.8 & 0 & 0 \\
\hline FHP2 & 43 & 17.4 & 30.8 & 7.8 & 0 & 1 \\
\hline FHP3 & 38 & 25 & 25 & 12 & 0 & 0 \\
\hline FHP4 & 37 & 25 & 25 & 12 & 0 & 1 \\
\hline FHP5 & 45 & 23 & 20 & 12 & 0 & 0 \\
\hline FHP6 & 44 & 23 & 20 & 12 & 0 & 1 \\
\hline FHP7 & 60 & 0 & 30 & 0 & 10 & 0 \\
\hline FHP8 & 59 & 0 & 30 & 0 & 10 & 1 \\
\hline
\end{tabular}

Table 7. Cooking quality of experimental high-protein pastas (Pasta HP).

\begin{tabular}{|c|c|c|c|c|c|c|c|c|c|}
\hline \multirow[b]{2}{*}{ Pasta } & \multirow[b]{2}{*}{ Protein (\%) } & \multirow{2}{*}{$\begin{array}{l}\text { Chemical } \\
\text { Score }\end{array}$} & \multirow[b]{2}{*}{ DIAAS (\%) } & \multirow{2}{*}{$\begin{array}{l}\text { Optimal } \\
\text { Cooking } \\
\text { Time (min) }\end{array}$} & \multicolumn{5}{|c|}{ Cooking Quality } \\
\hline & & & & & Firmness & Liveliness & $\begin{array}{l}\text { Starch } \\
\text { Release }\end{array}$ & $\begin{array}{l}\text { Total } \\
\text { Score }\end{array}$ & Panel Comments \\
\hline Pasta HP0 & $12.4 \pm 0.01^{\mathrm{h}}$ & 44 & 36 & $13^{\prime}: 00^{\prime \prime}$ & $100 \pm 0.0^{\mathrm{a}}$ & $90 \pm 4.71^{\text {a }}$ & $90 \pm 4.08^{b}$ & 93.3 & $\begin{array}{l}\text { Amber/yellow color, } \\
\text { pleasant smell and } \\
\text { taste, optimal } \\
\text { consistency }\end{array}$ \\
\hline Pasta HP1 & $50.6 \pm 0.02^{\mathrm{c}}$ & 91 & 100 & $14^{\prime}: 00^{\prime \prime}$ & $100 \pm 0.0^{\mathrm{a}}$ & $80 \pm 5.27^{b}$ & $80 \pm 3.33^{c}$ & 86.7 & $\begin{array}{l}\text { Light brown color, } \\
\text { pea flavor, excellent } \\
\text { consistency }\end{array}$ \\
\hline Pasta HP2 & $50.9 \pm 0.04^{b}$ & 91 & 100 & $14^{\prime}: 50^{\prime \prime}$ & $100 \pm 0.0^{\mathrm{a}}$ & $90 \pm 4.08^{\mathrm{a}}$ & $80 \pm 3.33^{c}$ & 90.0 & $\begin{array}{l}\text { Green color, pea smell, } \\
\text { excellent consistency }\end{array}$ \\
\hline Pasta HP3 & $54.5 \pm 0.10^{\mathrm{a}}$ & 100 & 100 & $15^{\prime}: 00^{\prime \prime}$ & $80 \pm 2.36^{c}$ & $\frac{80 \pm 5.27}{b c}$ & $90 \pm 6.24^{b}$ & 83.3 & $\begin{array}{l}\text { Light brown color, } \\
\text { mild pea flavor, good } \\
\text { consistency }\end{array}$ \\
\hline Pasta HP4 & $54.7 \pm 0.05^{\mathrm{a}}$ & 100 & 100 & $15^{\prime}: 00^{\prime \prime}$ & $90 \pm 7.07^{b}$ & $\underset{\mathrm{ac}}{85 \pm 4.71}$ & $90 \pm 4.08^{b}$ & 88.3 & $\begin{array}{l}\text { Green color, slight } \\
\text { herbaceous flavor, } \\
\text { good consistency }\end{array}$ \\
\hline Pasta HP5 & $50.1 \pm 0.11^{\mathrm{e}}$ & 95 & 100 & $14^{\prime}: 30^{\prime \prime}$ & $100 \pm 0.0^{\mathrm{a}}$ & $\underset{\mathrm{ac}}{85 \pm 4.71}$ & $80 \pm 4.71^{c}$ & 88.3 & $\begin{array}{c}\text { Light brown color, } \\
\text { pleasant taste, optimal } \\
\text { consistency }\end{array}$ \\
\hline Pasta HP6 & $50.4 \pm 0.05^{\mathrm{d}}$ & 95 & 100 & $15^{\prime}: 00^{\prime \prime}$ & $100 \pm 0.0^{\mathrm{a}}$ & $87 \pm 5.87^{a}$ & $80 \pm 2.36^{c}$ & 89.0 & $\begin{array}{l}\text { Green color, pleasant } \\
\text { flavor, optimal } \\
\text { consistency }\end{array}$ \\
\hline Pasta HP7 & $40.3 \pm 0.00^{g}$ & 100 & 100 & $15^{\prime}: 30^{\prime \prime}$ & $\begin{array}{l}97.5 \pm \\
4.24^{\mathrm{a}}\end{array}$ & $90 \pm 4.08^{\mathrm{a}}$ & $100 \pm 0.00^{a}$ & 95.8 & $\begin{array}{l}\text { Light brown color, } \\
\text { optimal consistency }\end{array}$ \\
\hline Pasta HP8 & $40.7 \pm 0.01^{\mathrm{f}}$ & 100 & 100 & $15^{\prime}: 30^{\prime \prime}$ & $98 \pm 2.58^{a}$ & $92 \pm 5.87^{\mathrm{a}}$ & $100 \pm 0.00^{\mathrm{a}}$ & 96.7 & $\begin{array}{l}\text { Green color, optimal } \\
\text { consistency }\end{array}$ \\
\hline
\end{tabular}

Different letters in a column indicate statistically significant differences $(p<0.05)$.

\section{Discussion}

The nutritional quality of a protein that is deficient in essential amino acids can be improved by suitable supplementation with other proteins rich in essential amino acids. Therefore, the addition of proteins from other sources in cereal-based formulations results in a complete and balanced level of essential amino acids.

The heterogeneity of raw materials (protein can come from both plant and animal sources) potentially usable in the production of cereal-based foods, and the replacement of all or part of the conventional flours with other cereals or ingredients different from cereals, often entails the need to make changes to the traditional production process. Balanced formulations and adequate technological processes must be adopted to compensate for any changes in functional properties caused by the incorporation of new ingredients $[12,32,33]$. 
The introduction of unconventional material in the recipe of commercial pasta (Table 1) definitely increased the protein content, especially if these are added at high levels. However, this impacted the quality attributes of pasta. In fact, besides a high protein content, the panelists' observations about smell, taste, texture and color were quite negative. To overcome this problem, with the aim of achieving optimal technological behavior that could have a positive influence on the cooking quality of the pasta, the formulations for innovative pasta were hypothesized, maintaining a higher percentage of semolina than the remaining ingredients (Table 6). The loss of firmness following the cooking caused by gluten deficiency, and the possible presence of unpleasant tastes and flavors due to alternative ingredients such as legumes, would prejudice the consumer's acceptance of the pasta. In fact, pasta compounds such as proteins, fat, and carbohydrates can absorb legumes' flavor compounds, resulting in their retention [34]. It thus means that the amount of pulse ingredient to add will be limited by flavor characteristics. Up to a certain percentage, the "off" flavor of the pulse ingredient can be masked by other compounds present in the food matrix [35].

To assess the improvement of the nutritional characteristics and the effects of the unconventional raw material's addition on the cooking quality of pasta, the protein content, the CS and the cooking quality were evaluated. Data in Table 7 show that all the experimental pasta had good protein contents (40.7-54.7\% fresh weight, f.w.), an improved CS (CS $=91-100)$ compared to the pasta with $100 \%$ semolina $(C S=44)$, and excellent cooking quality (total score between 83.3 and 96.7). To assess the protein quality of pasta, besides CS, the DIAAS\% was calculated. The actual capacity of protein to satisfy the amino acid needs requires the use of corrections for amino acid digestibility and availability. The FAO [1] recommendation is to use DIAAS as the measure of protein quality, rather than measures such as the protein efficiency ratio (PER). A nutritional claim for protein content (i.e., "source", "high" according to Regulation (EC) No 1924/2006 [36]) should be coupled to the computing of the DIAAS values, to discriminate the quality of the protein itself. For excellent/high-protein quality, DIAAS $\geq 100$ were proposed, for good/source values ranging from 75 to 99, while it was stated that no claim should be allowed for the cut-off value of, e.g., 75. All the recipes proposed in this experimentation led to the production of pasta with DIAAS higher than 100, showing the good combinations used to achieve high-quality protein in the final product.

The presence of a high content of semolina, egg white and whey proteins ensured the structuring of the pasta and therefore the cooking quality, achieving an evaluation comparable to the $100 \%$ semolina pasta used as a control. Pasta produced using formulation FPH7 and 8 in addition to having a protein content of $41.1 \%$ f.w. and optimal protein quality $(C S=100$, DIAAS $=100)$ higher than the control, among all the experimental pasta, showed the highest score for cooking quality. The results have shown that it is possible to produce nutritionally valid pasta with excellent cooking quality by only partially replacing the semolina and without adding adjuvants/additives, as used in and shown on most commercial pasta labels. Moreover, according to Regulation (EC) No 1924/2006 [36] and Commission Regulation (EU) No 432/2012 [37], all the pastas of this experimentation can boast both the nutrition claims (source of protein, high protein) and the health claims related to proteins, because they are foods that are at least a source of protein, as referred to in the claim source of protein, as listed in the Annex to Regulation (EC) No 1924/2006 [36].

Moreover, the presence of spirulina not only contributed to increasing the protein content, but in combination with pea protein and whey proteins, also determined a higher pasta firmness. According to Fradique et al. [38], the reinforcement of the gluten network could cause an extra establishment of disulfide bonds, formed between the sulfhydryl groups of cysteine residues in gluten proteins. Moreover, all pasta produced with spirulina showed an intense green color (Figure 1), which is less usual for pasta consumers, but this did not affect its acceptability because its taste and flavor were ordinary. The intense green color maintained by the pasta after the cooking (Figure 1) is also due to the fact that spirulina presents only chlorophyll $a$ in its constitution, which is more stable under 
thermal processes than the chlorophyll $b$ of vegetables, including the spinach generally used to color the products [39]. Similar observations have also recently been reported by Mostolizadeh et al. [40] using spirulina in pasta production.

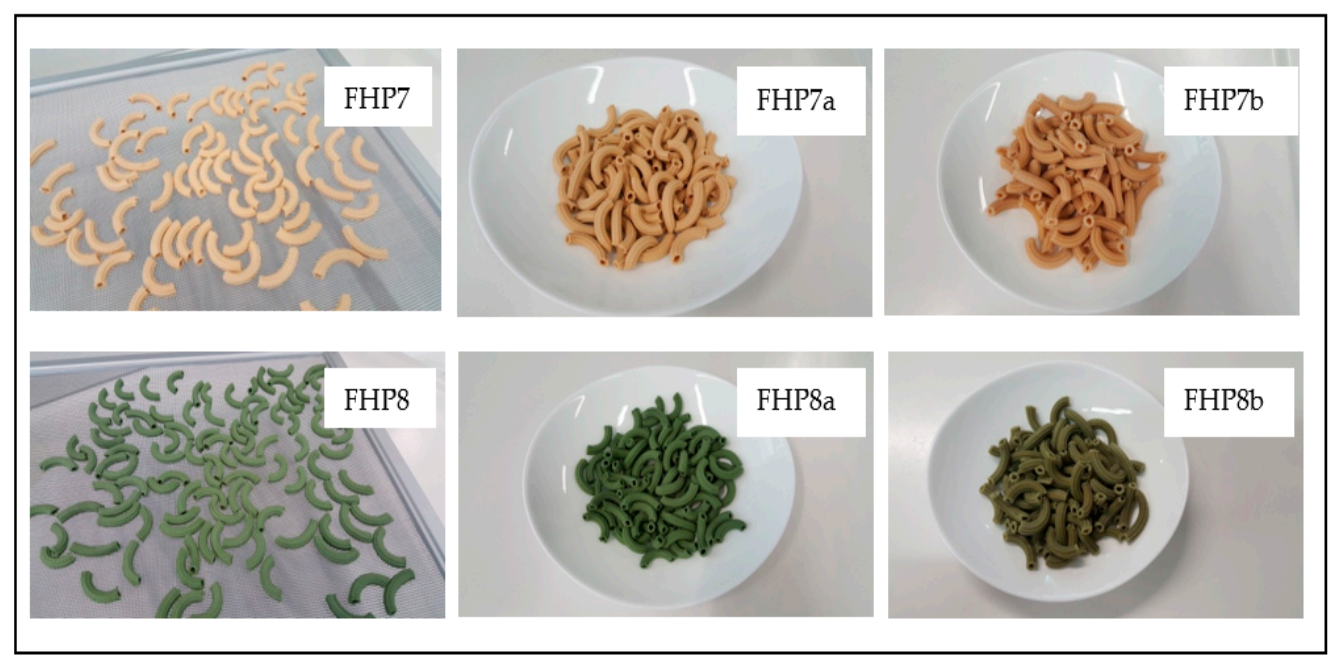

Figure 1. Raw (a) and cooked pasta (b) produced using formulation 7 (FHP7) and 8 (FHP8).

\section{Conclusions}

The study highlights the suitability of unconventional raw materials, such as legumes, whey proteins and spirulina, for obtaining pastas improved in terms of protein content, amino acids chemical score and cooking quality.

Good quality semolina (high protein, gluten strength) and its limited substitution with other ingredients is the key to obtaining pasta with a high cooking quality. Through suitable formulations it is possible to obtain not only the protein-enriched pasta, but also the amino acid complementarity useful for carrying out physiological functions and for ensuring the production of pasta with high-quality proteins. Spirulina, although in small concentrations, contributed to improving protein content, positively affecting the pasta firmness and leading to a green color in the product, which was stable even after processing and cooking.

Examples of fortified pasta produced in this experimentation may help to broaden the offer for people who want to improve the nutritional quality of their diet or satisfy the particular needs of sportsmen.

Author Contributions: Conceptualization, M.C.M. and E.M.; formal analysis, L.F., M.C.T., E.D.A.; data curation, M.C.M., F.C.; writing-original draft preparation, M.C.M., F.C., E.D.A.; writingreview and editing, M.C.M., E.M., F.C.; supervision, M.C.M., E.M.; funding acquisition, M.C.M., E.M. All authors have read and agreed to the published version of the manuscript.

Funding: This research received no external funding.

Informed Consent Statement: Not applicable.

Data Availability Statement: The data presented in this study are available on request from the corresponding author.

Conflicts of Interest: The authors declare no conflict of interest.

\section{References}

1. FAO/WHO. Dietary protein quality evaluation in human nutrition. FAO Food Nutr. Pap. 2013, 92, 1-66.

2. Società Italiana di Nutrizione Umana. Livelli di Assunzione di Riferimento di Nutrienti ed Energia per la Popolazione Italiana IV Revisione (LARN 2014). Available online: https:/ / sinu.it/tabelle-larn-2014/ (accessed on 12 January 2021).

3. Coleman, E. Protein requirements for athletes. Clin. Nutr. Insight 2012, 38, 1-3. [CrossRef] 
4. Lemon, P.W.; Tarnopolsky, M.A.; MacDougall, J.D.; Atkinson, S.A. Protein requirements and muscle mass/strength changes during intensive training in novice bodybuilders. J. Appl. Physiol. 1992, 73, 767-775. [CrossRef]

5. Moore, D.R.; Robinson, M.J.; Fry, J.L.; Tang, J.E.; Glover, E.I.; Wilkinson, S.B.; Prior, T.; Tarnopolsky, M.A.; Phillips, S.M. Ingested protein dose response of muscle and albumin protein synthesis after resistance exercise in young men. Am. J. Clin. Nutr. 2009, 89, 161-168. [CrossRef]

6. Poortmans, J.R.; Carpentier, A.; Pereira-Lancha, L.O.; Lancha, A., Jr. Protein turnover, amino acid requirements and recommendations for athletes and active populations. Braz. J. Med. Biol. Res. 2012, 45, 875-890. [CrossRef]

7. Tang, J.E.; Phillips, S.M. Maximizing muscle protein anabolism: The role of protein quality. Curr. Opin. Clin. Nutr. Metab. Care 2009, 12, 66-71. [CrossRef]

8. Tarnopolsky, M.A.; MacDougall, J.D.; Atkinson, S.A. Influence of protein intake and training status on nitrogen balance and lean body mass. J. Appl. Physiol. 1988, 64, 187-193. [CrossRef] [PubMed]

9. Pfeiffer, C.; Speck, M.; Strassner, C. What leads to lunch-How social practices impact (non-) sustainable food consumption/eating habits. Sustainability 2017, 9, 1437. [CrossRef]

10. Ranganathan, J.; Vennard, D.; Waite, R.; Dumas, P.; Lipinski, B. Shifting Diets for a Sustainable Food Future. Available online: http:/ / www.indiaenvironmentportal.org.in/files/file/Shifting_Diets_for_a_Sustainable_Food_Future.pdf (accessed on 6 December 2020).

11. Foschia, M.; Horstmann, S.W.; Arendt, E.K.; Zannini, E. Legumes as functional ingredients in gluten-free bakery and pasta products. Annu. Rev. Food Sci. Technol. 2017, 8, 75-96. [CrossRef] [PubMed]

12. Marconi, E.; Messia, M.C. Pasta made from non traditional raw materials: Technological and nutritional aspects. In Durum Wheat Chemistry and Technology; AACC International Press: St Paul, MN, USA, 2012.

13. Verardo, V.; Gómez-Caravaca, A.M.; Messia, M.C.; Marconi, E.; Caboni, M.F. Development of functional spaghetti enriched in bioactive compounds using barley coarse fraction obtained by air classification. J. Agric. Food Chem. 2011, 59, 9127-9134. [CrossRef] [PubMed]

14. Asif, M.; Rooney, L.W.; Ali, R.; Riaz, M.N. Application and opportunities of pulses in food system: A review. Crit. Rev. Food Sci. Nutr. 2013, 53, 1168-1179. [CrossRef] [PubMed]

15. Boukid, F.; Zannini, E.; Carini, E.; Vittadini, E. Pulses for bread fortification: A necessity or a choice? Trends Food Sci. Technol. 2019, 88, 416-428. [CrossRef]

16. Kadam, S.U.; Prabhasankar, P. Marine foods as functional ingredients in bakery and pasta products. Food Res. Int. 2010, 43, 1975-1980. [CrossRef]

17. Matos, Â.P. The impact of microalgae in food science and technology. J. Am. Oil Chem. Soc. 2017, 94, 1333-1350. [CrossRef]

18. Vendruscolo, R.G.; Fagundes, M.B.; Jacob-Lopes, E.; Wagner, R. Analytical strategies for using gas chromatography to control and optimize microalgae bioprocessing. Curr. Opin. Food Sci. 2019, 25, 73-81. [CrossRef]

19. Ciferri, O.; Tiboni, O. The biochemistry and industrial potential of Spirulina. Annu. Rev. Microbiol. 1985, 39, 503-526. [CrossRef]

20. Shimamatsu, H. Mass production of Spirulina, an edible microalga. Hydrobiologia 2004, 512, 39-44. [CrossRef]

21. da Silva, S.C.; Fernandes, I.P.; Barros, L.; Fernandes, Â.; Alves, M.J.; Calhelha, R.C.; Pereira, C.; Barreira, J.C.M.; Manrique, Y.; Colla, E. Spray-dried Spirulina platensis as an effective ingredient to improve yogurt formulations: Testing different encapsulating solutions. J. Funct. Foods 2019, 60, 103427. [CrossRef]

22. Chacón-Lee, T.L.; González-Mariño, G.E. Microalgae for "healthy" foods-possibilities and challenges. Compr. Rev. Food Sci. Food Saf. 2010, 9, 655-675. [CrossRef]

23. Iyer, U.M.; Dhruv, S.A.; Mani, I.U. Spirulina and its therapeutic implications as a food product. In Spirulina Human Nutrition and Health; Belay, A., Ed.; Crc Press, Taylor \& Francis Publishing group: Boca Raton, FL, USA, 2007; pp. 51-70.

24. Lafarga, T.; Fernández-Sevilla, J.M.; González-López, C.; Acién-Fernández, F.G. Spirulina for the food and functional food industries. Food Res. Int. 2020, 137, 109356. [CrossRef] [PubMed]

25. Grahl, S.; Strack, M.; Mensching, A.; Mörlein, D. Alternative protein sources in Western diets: Food product development and consumer acceptance of spirulina-filled pasta. Food Qual. Prefer. 2020, 84, 103933. [CrossRef]

26. Zen, C.K.; Tiepo, C.B.V.; da Silva, R.V.; Reinehr, C.O.; Gutkoski, L.C.; Oro, T.; Colla, L.M. Development of functional pasta with microencapsulated Spirulina: Technological and sensorial effects. J. Sci. Food Agric. 2020, 100, 2018-2026. [CrossRef]

27. European Commission. Farm to Fork Strategy-For a Fair, Healthy and Environmentally-Friendly Food System. 2020. Available online: https: / /ec.europa.eu/food/sites/food/files/safety/docs/f2f_action-plan_2020_strategyinfo_en.pdf (accessed on 2 December 2020).

28. ICC. Standard Methods of the International Association for Cereal Science and Technology; ICC: Vienna, Austria, 1995.

29. AACC. American Association of Cereal Chemists. Approved Methods of AACC, 10th ed.; The Association: St. Paul, MN, USA, 2000.

30. ISO. International Standard ISO 7304-1:2016, Durum Wheat Semolina and Alimentary Pasta—Estimation of Cooking Quality of Alimentary Pasta by Sensory Analysis. Available online: https://www.iso.org/standard/44312.html (accessed on 1 January 2021).

31. Laleg, K.; Barron, C.; Santé-Lhoutellier, V.; Walrand, S.; Micard, V. Protein enriched pasta: Structure and digestibility of its protein network. Food Funct. 2016, 7, 1196-1207. [CrossRef]

32. Marti, A.; Pagani, M.A. What can play the role of gluten in gluten free pasta? Trends Food Sci. Technol. 2013, 31, 63-71. [CrossRef] 
33. Petitot, M.; Boyer, L.; Minier, C.; Micard, V. Fortification of pasta with split pea and faba bean flours: Pasta processing and quality evaluation. Food Res. Int. 2010, 43, 634-641. [CrossRef]

34. Fischer, N.; Widder, S. How proteins influence food flavor: The chemistry of flavor interactions. Food Technol. 1997, 51, 68-70.

35. Roland, W.S.; Pouvreau, L.; Curran, J.; van de Velde, F.; de Kok, P.M. Flavor aspects of pulse ingredients. Cereal Chem. 2017, 94, 58-65. [CrossRef]

36. European Commission. Regulation (EC) No. 1924/2006 of the European Parliament and of the Council of 20 December 2006 on nutrition and health claims made on foods. Off. J. Eur. Union 2006, L404, 9-25.

37. European Commission. Regulation (EC) No. 432/2012 of 16 May 2012 establishing a list of permitted health claims made on foods, other than those referring to the reduction of disease risk and to children's development and health. Off. J. Eur. Union 2012, L136, 1-40.

38. Fradique, M.; Batista, A.P.; Nunes, M.C.; Gouveia, L.; Bandarra, N.M.; Raymundo, A. Incorporation of Chlorella vulgaris and Spirulina maxima biomass in pasta products. Part 1: Preparation and evaluation. J. Sci. Food Agric. 2010, 90, 1656-1664. [CrossRef] [PubMed]

39. Lemes, A.C.; Takeuchi, K.P.; de Carvalho, J.C.M.; Danesi, E.D.G. Fresh pasta production enriched with Spirulina platensis biomass. Braz. Arch. Biol. Technol. 2012, 55, 741-750. [CrossRef]

40. Mostolizadeh, S.S.; Moradi, Y.; Mortazavi, M.S.; Motallebi, A.A.; Ghaeni, M. Effects of incorporation Spirulina platensis (Gomont, 1892) powder in wheat flour on chemical, microbial and sensory properties of pasta. Iran. J. Fish. Sci. 2020, 19, 410-420. 